\title{
Inhibition by Lithium of the Hydroosmotic Action of Vasopressin in the Isolated Perfused Cortical Collecting Tubule of the Rabbit
}

\author{
Elie Cogan and Maurice Abramow \\ Laboratory of Experimental Medicine, Free University of Brussels and Queen Elisabeth Foundation, Brussels 1020, Belgium \\ Laboratory of Physiology and Pathophysiology, Free University of Brussels, Campus Erasme, Brussels 1070, Belgium
}

\begin{abstract}
Because treatment with lithium salts may impair renal concentrating ability, we investigated the possibility of a direct effect of lithium ions on the permeability to water of the collecting duct epithelium. The coefficient of hydraulic conductivity $\left(L_{p}\right)$ of isolated perfused rabbit cortical collecting tubules (CCT) was measured in the presence and absence of arginine-8-vasopressin (AVP), or 8-bromo (Br) cyclic AMP (cAMP) and/or lithium chloride ( $\mathrm{Li} 10 \mathrm{mM}$ ). In the absence of $\mathrm{AVP}, \mathrm{Li}$ in the lumen for $30 \mathrm{~min}$ failed to affect basal water permeability; however, in tubules preincubated with $\mathrm{Li}$ in the lumen for $80 \mathrm{~min}$, basal water permeability was reduced to $30 \%$ of the value found in control tubules $(P<0.01)$. In $\mathrm{CCT}$ incubated at $25^{\circ} \mathrm{C}$ with $\mathrm{Li}$ in the lumen for $3 \mathrm{~h}$, the hydroosmotic response to $2.5 \mu \mathrm{U} \cdot \mathrm{ml}^{-1}$ $\operatorname{AVP}\left(\mathrm{L}_{\mathrm{p}}=6.88 \pm 1.54 \mathrm{nl} \cdot \mathrm{cm}^{-2} \cdot \mathrm{s}^{-1} \cdot \mathrm{atm}^{-1}\right)$ was significantly lower than that in the control tubules $(13.98 \pm 1.59, P<0.01)$; the inhibition was not reversible. When $\mathrm{Li}$ was present in the peritubular medium only, the hydroosmotic effect of AVP was not different from that of the controls. The hydroosmotic effect of $25 \mu \mathrm{U} / \mathrm{ml} \mathrm{AVP}$ was investigated at $37^{\circ} \mathrm{C}$. CCT exposed to $L i$ in the lumen had a $49 \%$ inhibition of peak $L_{p}$ under AVP $\left(L_{p}=10.98 \pm 1.17\right)$ as compared with control tubules $\left(L_{p}\right.$ $=21.39 \pm 1.51 ; P<0.005)$. In contrast, the hydroosmotic response to 8-Br-cAMP was not affected by lithium. The results are compatible with the view that $\mathrm{Li}$ inhibits the action of AVP at the level of the regulating protein or the catalytic unit of the membrane adenylate cyclase and that the site of the interaction can be reached by lithium only from the cytoplasmic side. The Li-antidiuretic hormone (ADH) interaction found here may represent the earliest pathophysiological event underlying the renal concentrating defect observed after $\mathrm{Li}$ administration.
\end{abstract}

\section{Introduction}

Lithium salts are extensively used in the treatment of several disorders, mainly manic depressive psychosis (1). Unfortunately, important side effects have been reported in patients chronically treated with lithium (2-4). The most prominent was polyuria associated with polydipsia (5-10). The mechanisms of the polydipsia-polyuria syndrome have not been fully explained. Li may stimulate thirst directly or may occasionally induce a central type of diabetes insipidus by inhibiting antidiuretic hormone

This work was presented in part at the IIIrd European Colloquium on Renal Physiology, 1979, Uppsala, Sweden; and at the 17th Meeting of the European Society for Clinical Investigation, 1981, Basel, Switzerland.

Received for publication 11 July 1985.

J. Clin. Invest.

(c) The American Society for Clinical Investigation, Inc.

0021-9738/86/05/1507/08 $\$ 1.00$

Volume 77, May 1986, 1507-1514
$(\mathrm{ADH})^{1}$ release $(11-13)$. Nevertheless, the fully developed syndrome usually displays all the features of a nephrogenic type of diabetes insipidus $(6,9-11,13-15)$. Central to the clinical picture is a markedly impaired concentrating ability after dehydration that resists exogenous vasopressin in patients on long-term $\mathrm{Li}$ therapy $(6,16)$. In addition, $\mathrm{ADH}$ levels after dehydration were reported to be higher in patients on Li treatment as compared with controls (17, 18); Gold et al. (19) reported higher ADH levels in response to osmotic stimuli in patients on $\mathrm{Li}$ therapy. This argues against the hypothesis of a central origin of the polyuria. Other studies go further in analyzing the concentrating defect. Rats receiving lithium also developed vasopressin resistant polyuria $(6,20-22)$. Analysis of their renal tissue did not reveal suppression of the corticopapillary $\mathrm{Na}$ gradient (6). In a recent study conducted in rats chronically fed with lithium, a decrease in the medulla urea content was believed to contribute to the pathogenesis of the concentrating defect (23).

The effects of acute lithium administration had been tested in clearance studies in nonhuman primates (24) and also in man (13); in these experiments free water reabsorption was found to be significantly depressed, whereas free water clearance remained unchanged. Thus, on the basis of indirect approaches, the main component of the concentrating mechanism which is altered by lithium appears to reside in the water permeability properties of the collecting tubular epithelium rather than in the salt transporting capacity of the thick ascending limb of the loop of Henle. These results, however, were not confirmed in the rat where acute lithium administration inhibited salt transport in the loop of Henle (25). Several in vitro studies have attempted to clarify the mechanisms of the concentration defect induced by acute lithium administration. However, the results of these studies are largely controversial. The vasopressin-stimulated water flow in toad bladder is depressed by lithium in some (26-28) but not in other studies (29). Moreover, the side of the epithelium from which an effect of $\mathrm{Li}$ is demonstrated varies among the studies: mucosal Li is inhibiting in Singer et al. (26) experiments; serosal Li inhibits ADH action in Harris and Jenner's studies (27). There are also inconsistencies with regard to the concentrations of hormone needed to demonstrate the effect of $\mathrm{Li}$. Water flows stimulated by supramaximal doses of vasopressin are inhibited in Singer's study (26). In the more recent experiments of Tisher's group (28), only submaximal concentrations of the hormone produce an effect that is inhibitable by $\mathrm{Li}$. From studies on a mammalian cell system, the isolated rat papilla, it has been con-

1. Abbreviations used in this paper: ADH, antidiuretic hormone; AVP, arginine-8-vasopressin; CCT(s), cortical collecting tubules; $\mathrm{L}_{\mathrm{p}}$, coefficient of hydraulic conductivity; $L_{p 1}$, basal water permeability during control period; $L_{p 2}$, basal water permeability during experimental period; $L_{p 3}$, basal water permeability during postexperimental period; $L_{p A V P}$, value of $L_{p}$ under AVP; $L_{p}$ besel minimum steady state value of $L_{p} ; L_{p}$ 8-Br-cAMP, value of $L_{p}$ under 8-Br-cAMP; $\mathrm{Ni}$, inhibitory guanine nucleotide regulatory protein; $\mathrm{Ns}$, stimulatory guanine nucleotide regulatory protein. 
cluded that the water permeability response to ADH of the collecting duct is unaffected by $\mathrm{Li} \mathrm{(30)}$.

The purpose of the present study is to investigate directly the acute effects of lithium on the water permeability of the isolated perfused rabbit cortical collecting tubule. The choice of this segment of the nephron is justified by its crucial implication in the water conservation process.

\section{Methods}

New Zealand white rabbits, 1.2-2 kg in weight, were killed by decapitation after a short pentobarbital anesthesia. Collecting tubules were dissected from the cortex and perfused according to the general techniques of Burg et al. (31) as previously detailed (32). The range of the tubule lengths was 1.0-4.4 mm (mean, $2.15 \pm 0.10 \mathrm{SE}$ ). Experiments were performed at 25 or $37^{\circ} \mathrm{C}$. A temperature of $25^{\circ} \mathrm{C}$ is more suitable in attempts to uncover alterations of the hydroosmotic response to arginine-8-vasopressin (AVP) over long periods of time in the same tubule serving as its control $(32,33)$. On the other hand, experiments on cortical collecting tubules (CCTs) incubated at $37^{\circ} \mathrm{C}$ can be completed more rapidly but the response to AVP declines with time (34). CCTs were generally mounted in the perfusion set up within 20-30 min after the death of the animal. Both ends of the tubules were insulated from the bath with Sylgard 184 (35). A fluid exchange pipette, permitting complete replacement of the perfusate in $<1 \mathrm{~min}$ with the tubule in place, was mounted in the perfusion apparatus (35). The tubules were dissected and incubated in a modified Ringer's solution containing: $115 \mathrm{mM} \mathrm{NaCl}, 5 \mathrm{mM} \mathrm{KCl}$, $25 \mathrm{mM} \mathrm{NaHCO}, 10 \mathrm{mM} \mathrm{Na}$ acetate, $1.2 \mathrm{mM} \mathrm{NaH}_{2} \mathrm{PO}_{4}, 1.2 \mathrm{mM}$ $\mathrm{MgSO}_{4}, 1.0 \mathrm{mM} \mathrm{CaCl}, 5.5 \mathrm{mM}$ dextrose, and $5 \% \mathrm{vol} / \mathrm{vol}$ calf serum (Flow Laboratories, U.K.). The osmolality of the solution was $290 \mathrm{mOsm}$ $\mathrm{kg}^{-1}$ water. We constantly stirred and oxygenated the Ringer's solution by gently bubbling a $95 \% \mathrm{O}_{2}, 5 \% \mathrm{CO}_{2}$ mixture through it. The bathing medium was exchanged every $15 \mathrm{~min}$. A transtubular osmotic pressure difference was imposed by perfusing the tubule with a hypotonic solution. The latter was a Krebs Ringer phosphate buffer containing: $60 \mathrm{mM} \mathrm{NaCl}$, $2.5 \mathrm{mM} \mathrm{K}_{2} \mathrm{HPO}_{4}, 1.2 \mathrm{mM} \mathrm{MgSO}_{4}$, and $1.0 \mathrm{mM} \mathrm{CaCl}_{2}$. The osmolality of this solution was $125 \mathrm{mOsm} \mathrm{kg} \mathrm{g}^{-1} \mathrm{H}_{2} \mathrm{O}$. The $\mathrm{pH}$ of the perfusing solution was adjusted to 7.4 with $\mathrm{HCl}$. The lithium solutions were prepared by substituting equivalent amounts of $\mathrm{NaCl}$ for $\mathrm{LiCl}(10 \mathrm{mM})$ in the perfusing or bathing solutions. The driving force for perfusion was provided by a reservoir containing the perfusion solutions placed at $15-40 \mathrm{~cm}$ above the tip of the perfusion pipette. The perfusate contained ${ }^{125} \mathrm{I}$-iodothalamate $(25 \mu \mathrm{Ci} / \mathrm{ml}$ final activity) as a volume marker. The perfusion rate was measured as the amount of the volume marker recovered in the collecting pipette during each collection period (5-10 min) divided by the concentration of the marker in the perfusion fluid. The leak of perfusion fluid into the bathing medium was $<1 \%$ of the perfusion rate. When a more important leak was detected, the results of the experiments were discarded. The collection rate was measured as the volume of the fluid collected during the same period with a calibrated constant volume constriction pipette. The coefficient of hydraulic conductivity $\left(L_{p}\right)$ was calculated according to the following equation: $L_{p}=V r / \sigma S \overline{\Delta \pi}$, where $\mathrm{Vr}$ is the reabsorbed volume per minute, $\mathrm{S}$ is the area of the tubular membrane (calculated from the length and inner diameter of the tubule as measured with a micrometer eyepiece), $\sigma$ is the reflection coefficient of the solute, and $\overline{\Delta \pi}$ is the integrated mean difference between the osmotic pressures of the bath and of the luminal fluid. $\overline{\Delta \pi}$ was computed as reported by Dubois et al. (36). The osmolality of the collected fluid was estimated from the concentration of the volume marker in the sample assuming that changes in the osmolality of the tubular fluid were secondary only to water abstraction without any significant solute movement. This assumption is valid in the isolated collecting tubule in the presence or absence of vasopressin $(33,34,37)$. Another assumption is that $\sigma$ for the main osmotically active solute, $\mathrm{NaCl}$, is unity. This assumption has been verified to be true in the case of the CCT (38). $\mathrm{L}_{\mathrm{p}}$ was expressed in $\mathrm{nl} \cdot \mathrm{cm}^{-2} \cdot \mathrm{s}^{-1} \cdot \mathrm{atm}^{-1}$.
The radioactivity of the perfusate, the collected fluid, and the bathing medium were measured either in a manual gamma well counting system (ICN Tracerlab; ICN K\&K Laboratories, Inc., Plainview, NY) or in an automatic gamma counter (Packard Instrument Co., Downers Grove, IL). Counting times were set to give a $1 \%$ counting accuracy.

The experimental protocols involved eight groups of tubules that were divided into the following two sets of experiments.

\section{Experiments at $25^{\circ} \mathrm{C}$}

Group 1: control tubules $(n=9)$. The minimum steady state value of $L_{p}$, obtained $\sim 3 \mathrm{~h}$ after the death of the animal, is labeled $L_{p \text { basal }}$ in Results. This value is the average of two to three 5-10-min collection periods. The steady state value of $L_{p}$ under AVP $(2.5 \mu \mathrm{U} / \mathrm{ml})$ was measured in a similar fashion and labeled $L_{p A V P 1}$ in Results. The response to the hormone was calculated as the absolute increment in the coefficient of hydraulic conductivity. In four tubules used as time controls, the incubation with AVP was extended and $\mathrm{L}_{\mathrm{p} A \mathrm{P} P}$ was again determined 1 $h$ later (indicated $\mathrm{L}_{\mathrm{p} A \mathrm{VP} 2}$ ).

Group 2: effect of preincubation with $\mathrm{Li}$ in the lumen before adding $A V P$. The tubules were perfused with a solution containing lithium 10 $\mathrm{mM}(n=5)$ from the start of the experiment; after $\sim 3 \mathrm{~h}$ the minimum steady state value of $L_{p}$ was obtained and $L_{p \text { basal }}$ and $L_{p A V P 1}$ were computed as in group 1. The perfusion solution was then replaced by a lithium-free solution. $1 \mathrm{~h}$ later $\mathrm{L}_{\mathrm{p}}$ was again measured $\left(\mathrm{L}_{\mathrm{p} \text { AVP2 }}\right)$.

Group 3: effect of preincubation with $\mathrm{Li}$ in the peritubular medium before adding $A V P$. The tubules were perfused with a lithium free solution. The bathing solution contained $\mathrm{Li} 10 \mathrm{mM}$ during the $3 \mathrm{~h}$ required to obtain $L_{p}$ besal and thereafter during incubation with AVP. $L_{p}$ besel and $\mathbf{L}_{p \text { AVP1 }}$ were calculated as described above.

\section{Experiments at $37^{\circ} \mathrm{C}$}

Group 4: effect of short-time perfusion with $\mathrm{Li}$ on the basal water permeability. In the basal conditions of low water permeability, five tubules were perfused at lower perfusion rates $(2.5-6 \mathrm{nl} / \mathrm{min})$. The perfusion fluid was initially free of $\mathrm{Li}$ and $\mathrm{L}_{\mathrm{p} \text { besal }}$ was recorded after $60 \mathrm{~min}$ of perfusion ( $\mathrm{L}_{\mathrm{p} 1}$, control period) at which time it had decayed to its minimum level at $37^{\circ} \mathrm{C}(34)$. Thereafter, the perfusate was replaced by a solution containing $\mathrm{Li} 10 \mathrm{mM}$ during $30 \mathrm{~min}$ and $\mathrm{L}_{\mathrm{p}}$ was measured during this period $\left(L_{p 2}\right.$, experimental period). The perfusion fluid was then exchanged for the initial Li-free solution and the value of $L_{p}$ after 20 min of perfusion measured $\left(L_{p 3}\right.$, postexperimental period). $L_{p}$ values reported in the tables are the mean of the last two or three (5-7 min) collections during each period.

Group 5 and 6: control tubules: hydroosmotic response to AVP (group 5; $n=5$ ) or to 8 -Br-cAMP (group $6 ; n=7$ ). When the basal water permeabilities reached a low steady state value $\left(L_{p}\right.$ basal $)$ (generally after $80 \mathrm{~min})$ either AVP $(25 \mu \mathrm{U} / \mathrm{ml})$ or 8 -Br-cAMP $\left(10^{-4} \mathrm{M}\right)$ was added to the bathing medium. At $37^{\circ} \mathrm{C} \mathrm{AVP}$ and 8-Br-cAMP are known to induce prompt increases in $L_{p}$ but thereafter the hydraulic conductivity declines progressively with time (34). Therefore, the hydroosmotic effect of each agent was chosen as the peak value of $L_{p}$ and reported as $L_{p A v P}$ or $\mathrm{L}_{\mathrm{p} \text { 8-BreAMp. }}$ The hydroosmotic response to each agent is calculated as the difference between the stimulated and the basal state.

Groups 7 and 8: effect of luminal lithium on the hydroosmotic response to AVP (group 7; $n=5$ ) or to $8-B r-C A M P$ (group $8 ; n=7$ ). The same protocols as in groups 5 and 6 were followed except that the tubules were perfused with a solution containing $\mathrm{Li} 10 \mathrm{mM}$ from the beginning to the end of the experiment. Lithium was thus present in the luminal fluid for $\sim 80 \mathrm{~min}$ before adding AVP or 8-Br-cAMP to the bath.

\section{Reagents}

All chemical reagents used were obtained from Merck Laboratories (D-6100 Darmstadt, R.F.A.). AVP was synthetic arginine-8-vasopressin, a gift from Dr. Jan Mulder of Ferring, Sweden. The batch used had a potency of $430 \mathrm{UI} / \mathrm{mg}$. ${ }^{125}$ I-iodothalamate was obtained from Institut National des Radioéléments, Fleurus, Belgium. 


\section{Statistics}

Average values are given as mean \pm SE. Statistical significations were assessed by Student's $t$ test for paired or unpaired values. When the normality of the distribution was not evident the nonparametrical Wilcoxon test was used (39).

\section{Results}

\section{Control experiments (groups 1, 5, 6)}

At $25^{\circ} \mathrm{C}$ the hydraulic water permeability decreases with time to a nearly impermeable state after $\sim 180 \mathrm{~min}$. At this time, the mean $\mathrm{L}_{\mathrm{p}}$ value $\left(\mathrm{L}_{\mathrm{p} \text { basal }}=1.69 \pm 0.42 \mathrm{nl} \cdot \mathrm{cm}^{-2} \cdot \mathrm{s}^{-1} \cdot \mathrm{atm}^{-1}\right)$ is low, but significantly different from zero $(P<0.005)$. After adding AVP to the bathing medium, $L_{p}$ increases promptly and reaches a new steady state after $\sim 40 \mathrm{~min}\left(\mathrm{~L}_{\mathrm{p} \mathrm{AVP}}=15.67 \pm 1.45\right.$ $\left.\mathrm{nl} \cdot \mathrm{cm}^{-2} \cdot \mathrm{s}^{-1} \cdot \mathrm{atm}^{-1}\right)$. In the time-control tubules, $\mathrm{L}_{\mathrm{p} A \mathrm{AP1}}$ and $L_{p A V P 2}$ are not statistically different from each other, indicating that the hormone response remains stable after more than 120 $\min$.

At $37^{\circ} \mathrm{C}$, the basal $\mathrm{L}_{\mathrm{p}}\left(\mathrm{L}_{\mathrm{p} \text { basal }}=1.99 \pm 1.44 \mathrm{nl} \cdot \mathrm{cm}^{-2}\right.$. $\mathrm{s}^{-1} \cdot \mathrm{atm}^{-1}$ ) is reached after only $80 \mathrm{~min}$. The addition of AVP $(25 \mu \mathrm{U} / \mathrm{ml})$ in the bathing medium induces a prompt and sharp increase of $L_{p}$ (mean $L_{p A V P}$ peak value, 21.39 \pm 1.51 $\left.\mathrm{nl} \cdot \mathrm{cm}^{-2} \cdot \mathrm{s}^{-1} \cdot \mathrm{atm}^{-1}\right)$. The time-course of the osmotic water permeability in the experiments with 8 -Br-cAMP $\left(10^{-4} \mathrm{M}\right)$ (group 6) is quite similar to that observed under AVP. In both groups of tubules a sharp increase of $L_{p}$ is observed with a peak value being reached after $14.6 \mathrm{~min}$ for $8-\mathrm{Br}$-cAMP and $17.2 \mathrm{~min}$ for AVP (NS). Thereafter, $L_{p}$ falls progressively with time. The mean hydroosmotic effect of 8-Br-cAMP is significantly not different from that of AVP $\left(\Delta \mathrm{L}_{\mathrm{p} \text { 8-Br-cAMP }}=17.57 \pm 1.32 ; \Delta \mathrm{L}_{\mathrm{p} A V P}\right.$ $=19.40 \pm 1.87 ; P>0.20)$.

\section{Effect of luminal or peritubular lithium on the} hydroosmotic response to AVP at $25^{\circ} \mathrm{C}$ (Table I)

Preincubation with $\mathrm{Li}$ in the lumen (group 2). From the moment they were cannulated, the tubules were perfused with a solution containing $\mathrm{Li} 10 \mathrm{mM}$. Li was thus left in contact with the luminal border of the epithelium for $3 \mathrm{~h}$ before adding AVP. The mean value for $L_{p \text { basal }}$ was $0.61 \pm 0.47$. Under AVP and with $\mathrm{Li}$ remaining in the lumen, the water permeability increased significantly to $6.88 \pm 1.54 \mathrm{nl} \cdot \mathrm{cm}^{-2} \cdot \mathrm{s}^{-1} \cdot \operatorname{atm}^{-1}(P<0.05)$. The hydroosmotic response to the hormone of these tubules $\left(\Delta \mathrm{L}_{\mathrm{p}} \mathrm{AVP} 1\right.$ $\left.=6.27 \pm 1.27 \mathrm{nl} \cdot \mathrm{cm}^{-2} \cdot \mathrm{s}^{-1} \cdot \mathrm{atm}^{-1}\right)$ was significantly lower than that of the control tubules (group 1) $\left(\Delta \mathrm{L}_{\mathrm{p} \text { AVP1 }}=13.98 \pm 1.57 ; P\right.$ $<0.01$ ). Thus, lithium, when present in the lumen before adding AVP, induced a 55\% inhibition of the subsequent hydroosmotic hormone response. The inhibiting effect of $\mathrm{Li}$ was not reversible during the length of time of the experiment: the hormone response $1 \mathrm{~h}$ after withdrawing lithium from the perfusate remained significantly lower $\left(\Delta \mathrm{L}_{\mathrm{p} \mathrm{AVP2}}=4.65 \pm 1.35\right)$ than that of the time control tubules $\left(\Delta \mathrm{L}_{\mathrm{p} \text { AVP2 }}=11.87 \pm 0.44 ; P<0.005\right)$.

Preincubation with lithium in the bath (group 3). The osmotic water permeability reached a low steady state value after $\sim 3 \mathrm{~h}$ as in groups 1 and 2 . The mean $L_{p \text { basal }}$ was not significantly different from that of the control tubules. After vasopressin, the hydraulic conductivity significantly increased. The hydroosmotic response to the hormone $\left(\Delta \mathrm{L}_{\mathrm{p} A V P 1}=11.13 \pm 2.18\right)$ is of a magnitude similar to that of the control tubules $\left(\Delta \mathrm{L}_{\mathrm{p} \text { AVP1 }}\right.$ $=13.98 \pm 1.57 ; P>0.30$ ). Thus, lithium when present in the bath both before adding AVP and during exposure to AVP, leaves unaltered the basal water permeability and the subsequent hydroosmotic response to the hormone.

\section{Effect of luminal lithium on the hydroosmotic response to $\mathrm{AVP}$ at $37^{\circ} \mathrm{C}$ (Table II)}

The tubules were perfused with a solution containing 10 $\mathrm{mM} \cdot$ liter $^{-1} \mathrm{Li}$ immediately after cannulation (group 7). The hydroosmotic response to AVP, $25 \mu \mathrm{U} / \mathrm{ml}$, was markedly blunted in comparison with that of the control tubules. The maximal hydroosmotic response to the hormone under $\mathrm{Li}$ was $10.71 \pm 0.94 \mathrm{nl} \cdot \mathrm{cm}^{-2} \cdot \mathrm{s}^{-1} \cdot \mathrm{atm}^{-1}$, a value significantly lower than that of control tubules (group 5) $\left(\Delta \mathrm{L}_{\mathrm{p} \mathrm{AVP}}=19.40 \pm 1.87 ; P\right.$ $<0.01$ ). Thus, luminal lithium inhibits the hydroosmotic response to AVP at $37^{\circ} \mathrm{C}$ by $45 \%$.

\section{Effect of luminal lithium on the hydroosmotic response to 8-Br-CAMP at $37^{\circ} \mathrm{C}$ (Table III)}

The hydroosmotic response to 8 -Br-cAMP was $\Delta \mathrm{L}_{\mathrm{p}}=16.93$ \pm 2.88 in the tubules perfused with $\mathrm{Li}$ in the lumen from the start of the experiment (group 8). This value was only 3\% lower than that of control tubules (group 7) and the difference was not significant $(P=0.84)$. Thus, in contrast to that of AVP, the hydroosmotic response to 8 -Br-cAMP was not influenced by luminal lithium.

\section{Effect of lithium on the basal (ADH-independent) water permeability at $37^{\circ} \mathrm{C}$ (Fig. 1 and Table IV)}

Short time incubation experiments (Table IV). The tubules (group 4) were perfused at lower flow rates at $37^{\circ} \mathrm{C}$ (mean Vi $\left.=4.13 \pm 0.26 \mathrm{nl} \cdot \mathrm{min}^{-1}\right)$ in the absence of AVP or 8-Br-cAMP in the medium. With $\mathrm{Li}$ free perfusate, $\mathrm{L}_{\mathrm{p} \text { basal }}$ reached a steady state value after $\sim 80 \mathrm{~min}$ as in the other experiments performed at this temperature. At that time, $\mathrm{L}_{p \text { basal }}$ was $\mathrm{L}_{\mathrm{pl}}=1.61 \pm 0.57$ $\mathrm{nl} \cdot \mathrm{cm}^{-2} \cdot \mathrm{s}^{-1} \cdot \mathrm{atm}^{-1}$. The perfusate was then exchanged for a solution containing $\mathrm{Li} 10 \mathrm{mM}$ during $30 \mathrm{~min}$. This short-time perfusion with $\mathrm{Li}$ had no effect on the osmotic water permeability. In three experiments the perfusion solution was then switched back to the initial control perfusate without any significant change in $\mathrm{L}_{\mathrm{p}}$. These experiments did not demonstrate any immediate effect of luminal lithium incubation on the basal water permeability.

Preincubation with lithium (Fig. 1). In groups 7 and 8, the tubules were perfused with the lithium solution from the beginning of the experiment. The mean $L_{p \text { basal }}$ was $0.62 \pm 0.23$. This value was significantly lower than that found in control tubules (groups 5 and 6) perfused under similar experimental conditions but without $\mathrm{Li}$ in the lumen $\left(\mathrm{L}_{\mathrm{p}}=1.69 \pm 0.30 ; P<0.01\right)$. Thus, in these conditions lithium inhibited the ADH independent hydraulic conductivity by $>60 \%$.

\section{Discussion}

Our studies on the effects of lithium on the water permeability of the isolated collecting tubule of the rabbit were intended as a direct approach to the early mechanisms by which acute lithium administration can impair the renal concentrating ability in man and animals. The results of this study are the first to directly show that lithium can inhibit the hydroosmotic action of vasopressin in the mammalian collecting tubule. Lithium does interfere with the hormone action only in selected experimental conditions. Exposure of the luminal membrane to $\mathrm{LiCl}$ reduces the AVP-induced hydroosmotic action by $55 \%$ at $25^{\circ} \mathrm{C}$. This 
Table I. Basal Water Permeability and Hydroosmotic Response to AVP $(2.5 \mu \mathrm{U} / \mathrm{ml})$ in

Control Tubules and in Tubules Perfused with Lithium in the Lumen or in the Bath at $25^{\circ} \mathrm{C}$

\begin{tabular}{|c|c|c|c|c|c|c|c|}
\hline & $\begin{array}{l}\text { Experiment } \\
\text { No. }\end{array}$ & Vi & $\mathbf{L}_{\mathrm{P} \text { beat }}$ & $\mathbf{L}_{p A V P 1}$ & $\Delta \mathrm{L}_{\boldsymbol{D A V P 1}}$ & $\mathrm{L}_{\mathrm{DAVP}}$ & $\Delta \mathrm{L}_{\mathrm{PAVR}}$ \\
\hline & & $n l \cdot \min ^{-1}$ & $\mathrm{nl} \cdot \mathrm{cm}^{-2} \cdot \mathrm{s}^{-1} \cdot \mathrm{atm}^{-1}$ & $\mathrm{nl} \cdot \mathrm{cm}^{-2} \cdot \mathrm{s}^{-1} \cdot \mathrm{atm}^{-1}$ & $\mathrm{nl} \cdot \mathrm{cm}^{-2} \cdot \mathrm{s}^{-1} \cdot \mathrm{atm}^{-1}$ & $\mathrm{nl} \cdot \mathrm{cm}^{-2} \cdot \mathrm{s}^{-1} \cdot \mathrm{atm}^{-1}$ & $\mathrm{nl} \cdot \mathrm{cm}^{-2} \cdot \mathrm{s}^{-1} \cdot \mathrm{atm}^{-1}$ \\
\hline \multirow[t]{9}{*}{ Control (group 1) } & 1 & 18.9 & 1.68 & 11.25 & 9.57 & 12.73 & 11.75 \\
\hline & 2 & 20.3 & 1.09 & 14.47 & 13.38 & 12.53 & 11.44 \\
\hline & 3 & 13.0 & 1.55 & 16.04 & 14.49 & 14.63 & 13.08 \\
\hline & 4 & 15.4 & 1.38 & 13.24 & 11.86 & 13.30 & 11.92 \\
\hline & 5 & 17.2 & 3.72 & 16.05 & 12.33 & & \\
\hline & 6 & 18.5 & 1.17 & 26.38 & 25.21 & & \\
\hline & 7 & 22.7 & 2.12 & 13.52 & 11.40 & & \\
\hline & 8 & 15.2 & -0.63 & 16.39 & 17.02 & & \\
\hline & 9 & 14.2 & 3.16 & 13.68 & 10.52 & & \\
\hline \multirow[t]{2}{*}{ Mean \pm SE } & (1 to 9$)$ & 17.3 & 1.69 & $15.67^{*}$ & 13.98 & & \\
\hline & & 1.0 & 0.42 & 1.45 & 1.59 & & \\
\hline \multirow[t]{2}{*}{ Mean $\pm S E$} & (1 to 4$)$ & 16.9 & 1.43 & $13.75^{*}$ & 12.33 & $13.30^{*}$ & 11.87 \\
\hline & & 1.7 & 0.13 & 1.01 & 1.07 & 0.47 & 0.44 \\
\hline \multicolumn{8}{|c|}{ Lithium in the lumen } \\
\hline \multirow[t]{5}{*}{ (group 2) } & 10 & 16.7 & -0.12 & 9.47 & 9.59 & 7.16 & 7.28 \\
\hline & 11 & 14.7 & 1.83 & 5.39 & 3.56 & 4.17 & 2.34 \\
\hline & 12 & 12.7 & 0.61 & 1.47 & 0.86 & 2.27 & 1.66 \\
\hline & 13 & 12.5 & 1.47 & 8.78 & 7.31 & 5.00 & 3.53 \\
\hline & 14 & 15.4 & -0.73 & 9.31 & 10.04 & 7.70 & 8.43 \\
\hline \multirow[t]{2}{*}{ Mean \pm SE } & & 14.4 & 0.61 & $6.88 \ddagger$ & $6.27^{\prime \prime}$ & $5.26 \ddagger$ & $4.65 \pi$ \\
\hline & & 0.8 & 0.47 & $1.54^{\circ}$ & 1.27 & 0.99 & 1.35 \\
\hline \multicolumn{8}{|c|}{ Lithium in the bath } \\
\hline \multirow[t]{4}{*}{ (group 3) } & 15 & 13.2 & 7.64 & 14.78 & 7.14 & & \\
\hline & 16 & 17.3 & 2.47 & 19.68 & 17.21 & & \\
\hline & 17 & 19.5 & 0.38 & 9.43 & 9.05 & & \\
\hline & 18 & 14.5 & 1.70 & 12.81 & 11.11 & & \\
\hline \multirow[t]{2}{*}{ Mean \pm SE } & & 16.1 & 3.05 & $14.18 \S$ & 11.13 & & \\
\hline & & 1.4 & 1.59 & 2.14 & 2.18 & & \\
\hline
\end{tabular}

$\mathrm{Vi}$, mean perfusion rate for each experiment; $L_{p \text { basal }}$ and $L_{p A V P 1}$, hydraulic conductivity before and 40 min after adding AVP, respectively. $\Delta \mathrm{L}_{\mathrm{p} A V P 1}=\mathrm{L}_{\mathrm{pAVP1}}-\mathrm{L}_{\mathrm{p} \text { basal }}$ ("hormone response"). In tubules 1 to 4 (time control tubules) of group 1 and in all the tubules of group 2, $\mathrm{L}_{p}$ was again measured 60 min after $L_{p A V P 1}$ was obtained and labeled $L_{p A V P 2} . \Delta L_{p A V P 2}=L_{p A V P 2}-L_{p \text { besal }}$ is the hormone response during this period. Lithium was added at the start of the experiment either in the luminal fluid (group 2) or in the bath (group 3). ${ }^{*} P<0.001$ vs. basal values of the same tubule. $\ddagger P<0.050$ vs. basal values of the same tubule. $\S P<0.020$ vs. basal values of the same tubule. " $P<0.010$ vs. control tubules. I $P<0.005$ vs. control tubules.

inhibition of the action of physiological doses of AVP persists $1 \mathrm{~h}$ after removing lithium from the luminal fluid. Increasing the dosage of AVP to $25 \mu \mathrm{U} / \mathrm{ml}$, a concentration considered as maximal in other studies (40), and increasing the incubation temperature to $37^{\circ} \mathrm{C}$, which also enhances the response to AVP (34), do not alter the inhibitory effect of lithium.

The action of ADH on the water permeabilities of the target cells requires the generation of cAMP through the activation of the adenylate cyclase system $(41,42)$. To determine whether the $\mathrm{Li}-\mathrm{ADH}$ interaction affects the production or the effect of cAMP in the cell, we investigated the effect of $\mathrm{Li}$ on the hydroosmotic action of 8-Br-cAMP, a potent and stable derivative of cAMP that better resists the action of phosphodiesterase (43). The timecourse of the water permeability after $10^{-4} \mathrm{M} 8-\mathrm{Br}$-cAMP mimics that of AVP $(25 \mu \mathrm{U} / \mathrm{ml})$ at $37^{\circ} \mathrm{C}$, and in our control experiments the maximal hydroosmotic responses to both agents were not statistically different from each other. This suggests that the effect of 8-Br-cAMP $\left(10^{-4} \mathrm{M}\right)$ is functionally equivalent to the effect of maximal concentrations of AVP $(25 \mu \mathrm{U} / \mathrm{ml})$. Also of interest is the finding that $L_{p}$ under vasopressin is higher in the present studies than in previous work $(32,34)$. The hydroosmotic action of 8-Br-cAMP tested in the presence of lithium in the lumen was not different from that of the control. These results suggest that the major effect of lithium on vasopressin action may occur at a step preceding the generation of cAMP. In this framework, lithium probably acts at the level of one or another component of the membrane adenylate cyclase. Because lithium did not impair the vasopressin action when it was in contact with the basolateral membrane of the tubular cells, we consider it unlikely that the interaction occurs at the level of the hormone receptor itself. The inhibitory effect of $\mathrm{Li}$ probably lies in the deeper membrane domains, either at the catalytic unit of the adenylate 
Table II. Effect of Luminal Lithium on the Hydroosmotic Response to AVP $(25 \mu U / \mathrm{ml})$ at $37^{\circ} \mathrm{C}$

\begin{tabular}{|c|c|c|c|c|c|}
\hline & Experiment No. & $\mathrm{Vi}$ & $\mathbf{L}_{\mathrm{p}}$ & $\mathbf{L}_{\mathbf{P A V P I}}$ & $\Delta \mathrm{I}_{\mathrm{PAVP}}$ \\
\hline & & $n l \cdot \min ^{-1}$ & $\mathrm{nl} \cdot \mathrm{cm}^{-2} \cdot \mathrm{s}^{-1} \cdot \mathrm{atm}^{-1}$ & $\mathrm{nl} \cdot \mathrm{cm}^{-2} \cdot \mathrm{s}^{-1} \cdot \mathrm{atm}^{-1}$ & $\mathrm{nl} \cdot \mathrm{cm}^{-2} \cdot \mathrm{s}^{-1} \cdot \mathrm{atm}^{-1}$ \\
\hline \multirow[t]{5}{*}{ Control (group 5) } & 19 & 20.3 & 1.03 & 26.08 & 25.05 \\
\hline & 20 & 20.2 & 1.61 & 19.25 & 17.64 \\
\hline & 21 & 19.9 & 1.28 & 23.08 & 21.80 \\
\hline & 22 & 24.2 & 2.74 & 21.17 & 18.43 \\
\hline & 23 & 17.2 & 3.30 & 17.38 & 14.08 \\
\hline \multirow[t]{2}{*}{ Mean \pm SE } & & 20.4 & 1.99 & $21.39^{*}$ & 19.40 \\
\hline & & 1.1 & 0.44 & 1.51 & 1.87 \\
\hline \multirow[t]{5}{*}{ Lithium (group 7) } & 24 & 12.0 & -0.42 & 7.08 & 7.50 \\
\hline & 25 & 14.0 & 0.10 & 11.23 & 11.13 \\
\hline & 26 & 16.5 & 0.41 & 11.64 & 11.23 \\
\hline & 27 & 17.7 & 1.01 & 14.35 & 13.34 \\
\hline & 28 & 13.2 & 0.27 & 10.60 & 10.33 \\
\hline \multirow[t]{2}{*}{ Mean \pm SE } & & 14.7 & 0.27 & $10.98 * \S$ & $10.71 \ddagger$ \\
\hline & & 1.1 & 0.23 & 1.17 & 0.94 \\
\hline
\end{tabular}

See explanations in Table I. ${ }^{*} P<0.001$ vs. basal values. $\ddagger P<0.005$ vs. control values. $\S P<0.001$ vs. control values.

cyclase or at the level of the guanine nucleotide-binding regulatory proteins (Ns or $\mathrm{Ni}$ ). Ns couples the hormone-receptor complex to the catalytic unit of adenylate cyclase and mediates stimulation of adenylate cyclase activity, while $\mathrm{Ni}$ is responsible for inhibition (44). The existence of a GTP regulatory protein and its requirement for the activation of adenylate cyclase by vasopressin in the isolated CCT of the rabbit has been recently demonstrated in our laboratory (45); moreover, this regulatory protein was shown to be functionally active in our system (46). Lithium might theoretically exert its inhibitory effect by impairing Ns action. On the other hand, Anderson et al. (47) have recently reported that prostaglandins inhibit the hydroosmotic action of vasopressin through the activation of $\mathrm{Ni}$, the inhibitory regulating protein. Lithium might be active through a similar mechanism. Inhibition by lithium of the vasopressin-stimulated adenylate cyclase activity has been shown in the medullary por-

Table III. Effect of Luminal Lithium on the Hydroosmotic Response to 8-Br-cAMP $\left(10^{-4} \mathrm{M}\right)$ at $37^{\circ} \mathrm{C}$

\begin{tabular}{|c|c|c|c|c|c|}
\hline & Experiment No. & $\mathbf{V i}$ & $\mathbf{L}_{\mathrm{P}} \mathrm{ber}$ & L Lebreamp & $\Delta \mathrm{L}_{\mathrm{P} \text { erencher }}$ \\
\hline & & $n l \cdot \min ^{-1}$ & $\mathrm{nl} \cdot \mathrm{cm}^{-2} \cdot \mathrm{s}^{-1} \cdot \mathrm{atm}^{-1}$ & $\mathrm{nl} \cdot \mathrm{cm}^{-2} \cdot \mathrm{s}^{-1} \cdot \mathrm{atm}^{-1}$ & $\mathrm{nl} \cdot \mathrm{cm}^{-2} \cdot \mathrm{s}^{-1} \cdot \mathrm{atm}^{-1}$ \\
\hline \multirow[t]{7}{*}{ Control (group 6) } & 29 & 14.6 & 1.93 & 15.63 & 13.70 \\
\hline & 30 & 14.4 & 1.37 & 21.87 & 20.50 \\
\hline & 31 & 14.8 & 0.70 & 13.37 & 12.67 \\
\hline & 32 & 16.8 & 1.35 & 19.95 & 18.60 \\
\hline & 33 & 17.9 & 2.39 & 18.84 & 16.45 \\
\hline & 34 & 21.9 & 2.96 & 25.16 & 22.20 \\
\hline & 35 & 23.0 & -0.43 & 18.42 & 18.86 \\
\hline \multirow[t]{2}{*}{ Mean $\pm S E$} & & 17.6 & 1.47 & $19.03^{*}$ & 17.57 \\
\hline & & 1.3 & 0.42 & 1.47 & 1.32 \\
\hline \multirow[t]{7}{*}{ Lithium (group 8) } & 36 & 15.4 & 1.57 & 17.87 & 16.30 \\
\hline & 37 & 15.3 & 1.47 & 11.83 & 10.37 \\
\hline & 38 & 14.5 & 0.72 & 19.93 & 19.21 \\
\hline & 39 & 12.1 & -0.86 & 7.32 & 8.18 \\
\hline & 40 & 16.3 & 0.40 & 11.57 & 11.17 \\
\hline & 41 & 23.4 & 1.89 & 29.21 & 27.32 \\
\hline & 42 & 18.9 & 0.86 & 26.85 & 25.99 \\
\hline \multirow[t]{2}{*}{ Mean \pm SE } & & 16.6 & 0.86 & $17.80 \ddagger$ & 16.93 \\
\hline & & 1.4 & 0.35 & 3.09 & 2.88 \\
\hline
\end{tabular}

See Table II for explanations. The differences between means of group 6 and 8 are not statistically different. ${ }^{*} P<0.001$ vs. basal values. $\ddagger P<0.002$ vs. basal values. 


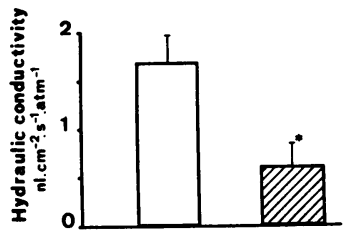

Figure 1. Effect of lithium on basal (AVP-independent) water permeability. The CCT were perfused at $37^{\circ} \mathrm{C}$ with (hatched columns) or without (open columns) $\mathrm{Li}$ in the perfusate for $80 \min \left({ }^{*} P<0.01\right)$.

tion of the collecting tubule of the rat (48). No data were available for the cortical segment.

Another important aspect in the action of lithium on the CCT revealed by the present study is that the ion is active only from the lumen. As lithium does not interfere with the hydroosmotic action of 8-Br-cAMP, an inhibitory effect at the level of the apical membrane itself is unlikely. It may be thus hypothetized that the ion enters the cell from the apical border and interferes at one or more steps in the vasopressin-induced changes leading to its hydroosmotic effect. An obvious experimental design to test the hypothesis would be to show that amiloride, which impairs lithium entry into epithelial cells (49), diminishes or abolishes the inhibitory effect of lithium. Unfortunately, in preliminary experiments amiloride unexpectedly could, of itself, inhibit the hydroosmotic effect of AVP (unpublished data). Since the inhibition by amiloride per se was of the same magnitude as that induced by lithium, any possible preventive effect of amiloride on lithium's inhibition could not be demonstrated. Thus, the hypothesis that lithium enters the cells from their apical border cannot be tested directly in our preparation. Nevertheless, convincing data from the literature favor this mechanism: (a) In other vasopressin responsive epithelia, lithium can substitute for $\mathrm{Na}$ in entering the amiloride sensitive channels of the apical membrane (50). As both the passive permeability to $\mathrm{Li}$ of the basolateral membrane and any primary or secondary active transport of lithium out of the cell presumably represent very small fluxes $(51,52)$, lithium tends to remain in the cell once it has crossed the apical border. (b) In the toad urinary bladder, amiloride prevents the lithium-induced inhibition of vasopressin

Table IV. Effect of Lithium in the Lumen on the Basal (ADH-independent) Water

Permeability at $37^{\circ} \mathrm{C}$ (Short-Time Incubation)

\begin{tabular}{|c|c|c|c|c|c|c|c|}
\hline & \multirow{2}{*}{$\begin{array}{l}\text { Experiment } \\
\text { No. }\end{array}$} & \multicolumn{2}{|c|}{ Control } & \multicolumn{2}{|c|}{ Experimental } & \multicolumn{2}{|c|}{$\begin{array}{l}\text { Post- } \\
\text { experimental }\end{array}$} \\
\hline & & $\mathbf{V i}_{\mathbf{1}}$ & $\mathbf{L}_{p 1}$ & $\mathrm{Vi}_{2}$ & $\mathrm{~L}_{\nabla 2}$ & $\mathrm{Vi}_{3}$ & $\mathbf{L}_{\mathbf{p} 3}$ \\
\hline & 43 & 3.83 & 1.47 & 4.93 & 1.85 & 3.83 & 1.80 \\
\hline & 44 & 3.53 & 2.62 & 3.95 & 3.70 & 4.04 & 3.18 \\
\hline & 45 & 4.49 & 3.13 & 4.06 & 2.57 & - & - \\
\hline & 46 & 3.24 & 0.77 & 4.20 & 0.62 & 2.55 & 0.49 \\
\hline & 47 & 5.94 & 0.06 & 5.87 & 1.01 & - & - \\
\hline \multirow[t]{2}{*}{ Mean \pm SE } & & 4.21 & 1.61 & 4.60 & 1.95 & 3.47 & 1.82 \\
\hline & & 0.48 & 0.07 & 0.36 & 0.55 & 0.47 & 0.78 \\
\hline
\end{tabular}

Same units as in Tables I to III. The indices 1, 2, 3 refer to the control (1), the experimental (2), or the postexperimental period (3). In period 2 , the perfusion fluid was exchanged for a solution containing $\mathrm{Li}$ (10 $\mathrm{mM}$ ) during 20-30 min. In three tubules (No. 43, 44, 46), the solution was exchanged back to control during period 3 . No significant differences between the parameters during the three periods could be demonstrated. stimulated water flows (26). (c) During acute lithium infusion, amiloride partially prevents the inhibitory effect of lithium on free water reabsorption both in the monkey (24) and in the rat (25).

In humans (13) and monkeys (24), acute lithium infusion diminishes free water reabsorption but not free water clearance, suggesting that the major target of lithium action lies at the level of fluid reabsorption in the collecting tubule. Only one study concludes that, in addition to its effect on water permeability, acute lithium infusion could inhibit $\mathrm{NaCl}$ transport in the loop of Henle during water diuresis (25). However, in these experiments on rats, the concentration reached by lithium in the plasma was extremely high. At these levels the relevance of these results to the pharmacological action of lithium on the concentrating mechanism is open to question.

From experiments conducted in the isolated rat papilla, Carney et al. (30) concluded that the water permeability response to ADH of the collecting duct is unaffected by lithium. In the present study we demonstrate that in the cortical portion of the rabbit collecting tubule, lithium indeed inhibits the hydroosmotic action of vasopressin. That inhibitory effect of lithium probably is of major significance because the cortical portion of the collecting tubule is known to be the segment of the nephron that reabsorbs the largest amount of water under $\mathrm{ADH}$. An impairment of the hydroosmotic action of vasopressin at the level of the CCT could overwhelm the capacity of more distal portions such as the papillary collecting duct to reabsorb water.

Another effect of lithium on water flow revealed by the present study is that exerted on the basal (ADH-independent) water permeability. As explained above, the basal water permeability is not zero in most studies $(32,33,40)$, although in some works it was sometimes not possible to measure it with sufficient accuracy to find it different from zero (53). Thus, there is some technical limitation in the measurement of osmotic water flow in the absence of ADH. For these reasons it seems more appropriate to express the hydroosmotic action of any agent in absolute $L_{p}$ or $\Delta L_{p}$ rather than in terms of a relative increase. Nevertheless, the fact that, as in the present study, the permeability to water can be shown to be significantly greater than zero in the collecting system may explain why, in the whole animal, urine can be less than maximally dilute in several states with complete lack of vasopressin (54). In the present study, incubation with lithium in the lumen for a period extending over $80 \mathrm{~min}$ clearly depressed the basal water permeability. More than 30 min contact time with $\mathrm{Li}$ is apparently required to observe this effect. The results illustrate the first reported instance of depression of ADH-independent water flows in the CCT. However, in the whole animal the consequences of the inhibition by lithium of the basal water permeability on the water homeostasis are difficult to evaluate but are probably of minor importance. While it is theoretically expected that during water diuresis (i.e., in the absence of vasopressin) a diminution of the basal hydraulic conductivity would enhance the generation of free water, this was not observed in studies testing the effects of acute lithium infusion on the free water clearance $(13,24,25)$. Nevertheless, we feel that the mechanism of the depression by lithium of the $\mathrm{ADH}$ independent water permeability is distinct from that underlying the impaired hydroosmotic action of vasopressin. If the AVP-independent mechanism was a basic component of the inhibitory effect of the hormone response, one would expect the hydroosmotic response to 8-Br-cAMP to be affected as well. This is clearly not the case. We thus may assume that any metabolic step not in- 
volving the increased generation of cAMP is not rate-limiting in the inhibitory effects of lithium on the hormone response.

In conclusion, we provide direct evidence that lithium inhibits the hydroosmotic action of vasopressin in the isolated CCT of the rabbit. The main site of action is probably at the level of the adenylate cyclase. To manifest its action on water conservation, lithium must be present at the luminal border of the tubular epithelium and probably needs to penetrate into the collecting tubule cells. We believe that the $\mathrm{Li}-\mathrm{ADH}$ interaction at the level of the cortical portion of the collecting duct is the major and earliest determinant of the renal concentrating defect observed in humans and animals treated with lithium.

\section{Acknowledgments}

The authors are indebted to Mrs. S. Foulon for technical assistance, to Mrs. M. N. Doutreluingne for secretarial assistance, and to Mrs. Lotteau for drawing the figure.

These presented were supported by a grant from the Fonds de la Recherche Scientifique Médicale (No. 3.4532.83). Dr. E. Cogan has received fellowships from the Fonds Lekime Ropsy and the Fonds Solvay.

\section{References}

1. Schou, M. 1959. Lithium in psychiatric therapy. Psychopharmacologia. 1:65-78.

2. Baldessarini, R. J., and J. F. Lipinski. 1975. Lithium salts: 19701975. Ann. Intern. Med. 83:527-533.

3. Singer, I., and D. Rotenberg. 1973. Mechanisms of lithium action. N. Engl. J. Med. 298:254-260.

4. Vestergaard, P. 1983. Clinically important side effects of longterm lithium treatment: a review. Acta Psychiatr. Scand. 67(Suppl.):136.

5. Angrist, B. M., S. Gershon, S. J. Levitan, and A. G. Blumberg. 1970. Lithium-induced diabetes insipidus-like syndrome. Compr. Psychiatry. 11:141-146.

6. Forrest, J. N., Jr., A. D. Cohen, J. Torretti, J. M. Himmelhoch, and $\mathrm{F}$. H. Epstein. 1974. On the mechanism of $\mathrm{Li}$-induced diabetes insipidus in man and the rat. J. Clin. Invest. 53:1115-1123.

7. Baylis, P. H., and D. A. Heath. 1978. Water disturbances in patients treated with oral lithium carbonate. Ann. Intern. Med. 88:607-609.

8. Price, T. A., and P. J. Beisswenger. 1978. Lithium and diabetes insipidus. Ann. Intern. Med. 88:576-577.

9. Battle, D., M. Gaviria, M. Grupp, J. A. L. Arruda, J. Wynn, and N. A. Kurtzman. 1982. Distal nephron function in patients receiving chronic lithium therapy. Kidney Int. 21:477-485.

10. Gerner, R. H., J. Psarras, and M. A. Kirshenbaum. 1980. Results of clinical renal function tests in lithium patients. Am. J. Psychiatry. 137:834-837.

11. Cox, M., and I. Singer. 1975. Lithium and water metabolism. Am. J. Med. 59:153-157.

12. Smith, D. F., S. Balagura, and M. Lubran. 1970. "Antidotal thirst": a response to intoxication. Science (Wash. DC). 167:297-298.

13. Singer, I., D. Rotenberg, and J. B. Puschett. 1972. Lithiuminduced diabetes insipidus: in vivo and in vitro studies. J. Clin. Invest. 51:1081-1091.

14. Lee, R. V., L. M. Jampol, and W. V. Brown. 1971. Nephrogenic diabetes insipidus and lithium intoxication: complications of lithium carbonate therapy. $N$. Engl. J. Med. 284:93-94.

15. Ramsey, T. A., J. Mendels, J. W. Stokes, and R. G. Fitzgerald. 1972. Lithium carbonate and kidney function. JAMA (J. Am. Med. Assoc.). 219:1446-1449.

16. Bendz, H. 1983. Kidney function in lithium-treated patients. A literature survey. Acta Psychiatr. Scand. 68:303-324.

17. Hansen, H. E., E. B. Pedersen, H. Orskov, P. Vestergaard, A. Amidsen, and M. Schou. 1982. Plasma arginine-vasopressin, renal con- centrating ability and lithium excretion in a group of patients on long term lithium treatment. Nephron. 32:125-130.

18. Padfield, P. L., S. J. Park, J. J. Morton, and A. E. Braidwood. 1977. Plasma levels of antidiuretic hormone in patients receiving prolonged lithium therapy. Br. J. Psychiatry. 130:144-147.

19. Gold, P. W., G. L. Robertson, R. M. Post, W. Kaye, J. Ballenger, D. Rubinow, and F. F. Godwin. 1983. The effect of lithium on the osmoregulation of vasopressin secretion. J. Clin. Endocrinol. Metab. 56: 295-299.

20. Thomsen, K. 1970. Lithium-induced polyuria in rats. Int. Pharmacopsychiatry. 5:233-241.

21. Hochman, S., and Y. Gutman. 1974. Lithium: ADH antagonism and ADH independent action in rats with diabetes insipidus. Eur. $J$. Pharmacol. 28:100-107.

22. Christensen, S. 1974. Effects of water deprivation in rats with polydipsia and polyuria due to long term administration of lithium. Acta Pharmacol. Toxicol. 35:201-211.

23. Christensen, S., E. Kusano, A. N. K. Yusufi, N. Muruyama, and T. P. Dousa. 1985. Pathogenesis of nephrogenic diabetes insipidus due to chronic administration of lithium in rats. J. Clin. Invest. 75:18691879.

24. Webb, R. K., P. B. Woodhall, C. C. Tisher, and R. R. Robinson. 1975. Acute effects of $\mathrm{Li}$ on the renal concentrating mechanism in a primate. Am. J. Physiol. 228:909-914.

25. Martinez-Maldonado, M., and S. Opava-Stitzer. 1977. Distal nephron function of the rat during lithium chloride infusion. Kidney Int. 12:17-22.

26. Singer, I., and E. A. Franko. 1973. Lithium-induced ADH resistance in toad urinary bladders. Kidney Int. 3:151-159.

27. Harris, C. A., and F. A. Jenner. 1972. Some aspects of the inhibition of the action of antidiuretic hormone by lithium ions in the rat kidney and bladder of the toad Bufo Marinus. Br. J. Pharmacol. 44: 223-232.

28. Fernandez-Repollet, E., A. LeFurgey, M. A. Hardy, and C. C. Tisher. 1983. Structural and functional response of toad urinary bladder to LiCl. Kidney Int. 24:719-730.

29. Bentley, P. J., and A. Wasserman. 1972. The effects of lithium on the permeability of an epithelial membrane: the toad urinary bladder. Biochim. Biophys. Acta. 266:285-292.

30. Carney, S., B. Rayson, and T. Morgan. 1976. The effect of lithium on the permeability response induced in the collecting duct by antidiuretic hormone. Pflüegers Arch. Eur. J. Physiol. 366:19-23.

31. Burg, M., J. Grantham, M. Abramow, and J. Orloff. 1966. Preparation and study of fragments of single rabbit nephrons. Am. J. Physiol. 210:1293-1298.

32. Abramow, M. 1974. Effects of ethacrynic acid on the isolated collecting tubule. J. Clin. Invest. 53:796-804.

33. Abramow, M. 1975. La perméabilité à l'eau du tubule collecteur isolé et perfusé. Effets de l'hormone antidiurétique et de certains diurétiques. Thesis. Free University of Brussels.

34. Hall, D. A., and J. J. Grantham. 1980. Temperature effect on ADH response of isolated perfused rabbit collecting tubules. Am. J. Physiol. 239:595-601.

35. Burg, M. 1972. Perfusion of isolated renal tubules. Yale J. Biol. Med. 45:321-326.

36. Du Bois, R., A. Verniory, and M. Abramow. 1976. Computation of the osmotic water permeability of perfused tubule segments. Kidney Int. 10:478-479.

37. Frindt, G., E. E. Windhager, and A. Taylor. 1982. Hydroosmotic response of collecting tubules to ADH or CAMP at reduced peritubular sodium. Am. J. Physiol. 243:503-513.

38. Schafer, J. A., and T. E. Andreoli. 1972. The effects of antidiuretic hormone on solute flows in mammalian collecting tubules. J. Clin. Invest. 51:1279-1286.

39. Schwartz, D. Méthodes statistiques à l'usage des médecins et des biologistes. 1981. Flammarion, Médecine-Sciences. 318 pp.

40. Grantham, J. J., and J. Orloff. 1968. Effect of prostaglandin E1 on the permeability response of the isolated collecting tubule to vaso- 
pressin, adenosine $3^{\prime}, 5^{\prime}$-mono phosphate, and theophylline. J. Clin. Invest. 47:1154-1161.

41. Grantham, J. J., and M. B. Burg. 1966. Effect of vasopressin and cyclic AMP on permeability of isolated collecting tubules. Am. J. Physiol. 211:255-259.

42. Dousa, T. P., and H. Valtin. 1976. Cellular action of vasopressin in the mammalian kidney. Kidney Int. 10:46-63.

43. Meyer, R. B., and J. P. Miller. 1974. Analogs of cyclic AMP and cyclic GMP: general methods of synthesis and the relationship of structure to enzymatic activity. Life Sci. 14:1019-1040.

44. Rodbell, M. 1980. The role of hormone receptors and GTPregulatory proteins in membrane transduction. Nature (Lond.). 284:1722.

45. Cogan, E., A. da Luz Duque, and M. Abramow. 1984. Activation of adenylate cyclase by vasopressin in the isolated collecting tubule involves a GTP regulatory protein. IXth International Society of Nephrology; Abstr. 409.4.

46. Cogan, E., and M. Abramow. 1985. Physiological analysis of the components of the adenylate cyclase system involved in the water permeation of the isolated collecting tubule of the rabbit kidney. Arch. Int. Physiol. Biochim. 93:22-23.

47. Anderson, R. J., P. D. Wilson, M. A. Dillingham, R. Breckson,
U. Schwertslag, and J. A. Garcia-Sainz. 1985. Pertussis toxin reverses prostaglandin E2 inhibition of arginine vasopressin and forskolin in rabbit collecting tubular epithelium. Kidney Int. 27:252 (abstr.).

48. Jackson, B. A., R. M. Edwards, and T. P. Dousa. 1980. Lithiuminduced polyuria: effect of lithium on adenylate cyclase and adenosine 3',5'-monophosphate phosphodiesterase in medullary ascending limb of Henle's loop and in medullary collecting tubules. Endocrinology. 107: 1693-1698.

49. Herrera, F. C. 1972. Inhibition of lithium transport across toad bladder by amiloride. Am. J. Physiol. 222:499-502.

50. Leblanc; G. 1972. The mechanism of lithium accumulation in the isolated frog skin epithelium. Pflüegers Arch. Eur. J. Physiol. 337: $1-18$.

51. Diamond, J. M., B. E. Erlich, S. G. Morawski, and C. A. Santa Ana. 1983. Lithium absorption in tight and leaky segments of intestine. J. Membr. Biol. 72:153-159.

52. Erlich, B. E., and J. M. Diamond. 1980. Lithium, membranes and manic depressive illness. J. Membr. Biol. 52:187-200.

53. Gross, J. B., M. Imaï, and J. P. Kokko. 1975. A functional comparison of the cortical collecting tubule and the distal convoluted tubule. J. Clin. Invest. 55:1284-1294.

54. Harrington, A. R. 1972. Hyponatremia due to sodium depletion in the absence of vasopressin. Am. J. Physiol. 222:768-774. 